\title{
Big Pharma Gives Millions to Congress
}

Pharmaceutical companies contribute millions of dollars to U.S. senators and representatives as part of a multipronged effort to influence health care lawmaking and spending priorities. Kaiser Health News (KHN) recently developed a database of contributions by pharmaceutical manufacturers to members of Congress for the past 10 years (1). This was done by examining campaign finance reports from the Federal Election Commission to track donations from political action committees (PACs). The amounts are totaled quarterly and the exact amounts but can change as amendments and refunds are reported. Occasionally, refunds are reported in a different cycle from the original contribution, resulting in a negative total for the cycle. The database can be used to look up any individual candidate or pharmaceutical company and will be updated periodically according to KHN. Contributions to members of Congress from the Southwest states of Arizona, California, Colorado, Hawaii, Nevada and New Mexico are summarized in Appendix 1.

The drug industry ranks among lawmakers' most generous patrons. In the past decade, Congress has received $\$ 79$ million from 68 pharma political action committees, or PACs, run by employees of companies that make drugs. The amount has steadily increased each year from $\$ 11.8$ million in 2008 to $\$ 15.8$ million last year. Since the beginning of last year, 34 lawmakers have each received more than $\$ 100,000$ from pharmaceutical companies. In the Southwest one of those - Rep. Kevin McCarthy of California, the House Republican majority leader, received more than $\$ 200,000$ so far this election cycle (2017 and 2018 to date) and has received more than $\$ 1,000,000$ over the past 10 years (Appendix 1).

While PAC contributions to candidates are limited, a larger donation frequently accompanies individual contributions from the company's executives and other employees. According to Medpage Today, it also sends a clear message to the recipient, one they may remember when lobbyists come calling: "There's more where that came from" (2).

The $\mathrm{KHN}$ analysis shows that pharmaceutical companies give generously to a wide swath of lawmakers. Since the beginning of 2017, drug makers contributed to 217 Republicans and 187 Democrats, giving only slightly more on average to Republicans, who currently control both chambers of Congress (2). This was also the case for Democrats during the 2010 election cycle, when they controlled Congress.

Money also tends to flow to congressional committees with jurisdiction over pharmaceutical issues that can affect things like drug pricing and FDA approval. in early 2017, For Example, Rep. Greg Walden from Oregon has watched his coffers swell since he became chairman of the powerful House Committee on Energy and Commerce (1). Walden has received over $\$ 278,000$ this election cycle. The six members of the committee from Southwest states (Reps. Walters, Eshoo, DeGette, Matsui, McNerney, and Peters) have also received $\$ 415,500$ to date. 
Nearly 50 drug makers made contributions with the amount roughly following the size of the company. Genentech, Pfizer, Amgen, Bristol-Myers Squibb and Eli Lilly were the top 5 over the past 10 years. The PAC for Purdue Pharma, the embattled opioid manufacturer, gave to only a handful of members this cycle. However, it focused much of its giving on lawmakers from North Carolina, its headquarters for manufacturing and technical operations. Insys, the opioid manufacturer from Chandler, Arizona, was not listed as making any contributions.

Campaign contributions tell only part of the story. Drugmakers also spend millions of dollars lobbying members of Congress. So far over $\$ 430$ million has been spent this election cycle by pharmaceutical companies lobbying Congress (3). Another source is indirect lobbying through to patient advocacy groups, which provide patients to testify on Capitol Hill and organize social media campaigns on drug makers' behalf. A previous investigation by Kaiser Health News, "Pre\$cription for Power," examined charitable giving by top drugmakers and found that 14 of them donated a combined $\$ 116$ million to patient advocacy groups in 2015 alone (4).

Previous studies have suggested that political contributions may influence voting behavior. These sizable contributions may help explain, at least in part, why drug prices in the US are the highest in the world and why Congressional legislation regulating these prices has been so difficult to pass.

Richard A. Robbins, MD

Editor, SWJPCC

\section{References}

1. Lucas E, Lupkin S. Pharma cash to Congress. Kaiser Health News. October 16, 2018. Available at: https://khn.org/news/campaign/ (accessed 10/23/18).

2. Huetteman E, Lupkin S. Drugmakers funnel millions to lawmakers. Medpage Today. October 16, 2018. Available at: https://www.medpagetoday.com/washingtonwatch/electioncoverage/75737?xid=nl mpt investigative2018-1023\&eun=g687171 $\mathrm{d} 0 \mathrm{r} \& u t m$ source $=$ Sailthru\&utm medium $=$ email\&utm campaign $=$ In vestigateMD 102318\&utm term=InvestigativeMD (accessed 10/23/18).

3. Pharmaceuticals/health products. OpenSecrets.org. August 28, 2018. Available at: https://www.opensecrets.org/lobby/indusclient.php?id=h04 (accessed 10/23/18).

4. Kopp E, Lucas E, Lupkin S. Pre\$cription for power. Kaiser Health News. 2018. Available at: https://khn.org/patientadvocacy/\#+initialWidth=1170\&childld=patient advocacy\&parentTitle=Pre\%24criptio n\%20For\%20Power\%3A\%20KHN\%20Patient\%20Advocacy\%20DatabaseKaiser\%2 0Health\%20News\&parentUrl=https\%3A\%2F\%2Fkhn.org\%2Fpatient-advocacy\%2F (accessed 10/23/18). 